\title{
TELECOMMUTING IN QUARANTINE AND SELF-ISOLATION DURING THE COVID-19 PANDEMIC
}

УДК 159.9:331.101.3

DOI https://doi.org/10.32843/2663-

5208.2020.16.33

\section{Руденок А.І.}

к.психол.н., доцент кафедри психології та педагогіки

Хмельницький національний університет

\section{Петяк О.В.}

старший викладач кафедри психології та педагогіки

Хмельницький національний університет

Ханецька Н.В.

к.психол.н., доцент кафедри психології та педагогіки

Хмельницький національний університет

\begin{abstract}
у статті розглянуті ключові аспекти дистанційноїзайнятостів вучасних соціально-економічних умовах, описані різновиди телероботи, виділені переваги та труднощі, з якими може стикнутися роботодавець та працівники під час переходу на віддалену роботу. Сучасні реалії вимагають від суспільства мобільності, інноваційних підходів та швидкоїадаптаціїдо непростих умов життя та роботи в період пандемії COVID-19. Введення режиму самоізоляції, карантину на такий тривалий термін в нашій країні, на наш погляд, актуалізує переведення майже всіх видів праці на дистанційний фоормат роботи (крім тих, які неможливо здійснювати у даному вигляді). Тому на чей час науковиям усього світу важливо проаналізувати цю ситуацію та можливі проблеми, перешкоди і знайти оптимальні рішення та рекомендації, які допомогли б максимально якісно та комсоотно продовжувати трудову діяльність, використовуючи особистісні та соціальні ресурси.

у статті здійснене практичне дослідження ставлення студентів, які працюють та навчаються у Хмельницькому національному університеті, до дистанційної роботи в умовах самоізоляції, визначені недоліки такого формату праці та з'ясована залежність орієнтації на дистанційну роботу в майбутньому від типу темпераменту респондентів. Загалом було з'ясовано, що існують значні індивідуальні особливості в здатності людей справлятися з соціальною ізоляцією та обмеженнями в період карантину під час трудової дистанційної діяльності. Важливість та актуальність максимального переведення працівників у формат віддаленої роботи зумовлюється транспортними проблемами в містах-мегаполісах, величезними і малоефективними втратами пального під час проїзду до місия роботи і назад, довготривалому перебуванні в автодорожніх «заторах» $і$ найважливіше безпекою життя та здоров'я в сучасних реаліях боротьби з пандемією COVID-19. Оскільки дистанційна робота відкриває нові можливості працевлаштування не лише для інвалідів, матусь у декретних відпустках з маленькими дітьми, але і для працівників тих численних профресій, чия присутність в офрісі, в стінах підприємства зовсім необов'язкова.
\end{abstract}

Ключові слова: віддалена робота, дистанційна форма праці, карантин, особливості роботи з дому, телеробота.

The article examines the key aspects of distance employment in modern socio-economic conditions, describes the types of telework, highlighted the advantages and difficulties that an employer and employees may face when switching to remote work. Modern realities require society to be mobility, innovative approaches and quick adaptation to difficult living and working conditions during the COVID-19 pandemic. The introduction of a self-isolation regime, quarantine for such a long period in our country, in our opinion, actualizes the transfer of almost all types of labor to a remote work format (except for those that cannot be carried out in this form). Therefore, at the moment, it is important for scientists all over the world to analyze this situation and possible problems, obstacles and find optimal solutions and recommendations that would help to continue working with the highest quality and comfort, using personal and social resources.

The article carried out a practical study of the attitude of students, work and study at the Khmelnytsky National University remote work in conditions of self-isolation, certain disadvantages of this work format and clarified the dependence of the orientation towards remote work in the future on the type of respondents' temperament. In total, it was found that there are significant individual characteristics in the ability of people to cope with social isolation and restrictions during the quarantine period during remote work. The importance and relevance of the maximum transfer of workers to the format of remote work is determined by transport problems in metropolitan cities, huge and ineffective fuel losses when traveling to and from work, a long stay in traffic jams, and the most important thing is the safety of life and health in modern realities fighting the COVID-19 pandemic. Since remote work opens up new employment opportunities not only for disabled people, mothers on maternity leave with small children, but also workers of those numerous professions whose presence in the office, within the walls of the enterprise, is not at all necessary.

Key words: remote work, remote form of work, quarantine, features of work from home, telework.
Постановка проблеми. Протягом останнього десятиліття дистанційна зайнятість у світі набула значного поширення. Все більше молодих та амбітних співробітників переходить на віддалену роботу, облаштовуючи робоче місце у власній квартирі, в кафе, в клієнтських офісах або іншому зручному для роботи місці. Роботодавці частіше стали приділяти увагу такому поняттю, як дистанційна зайнятість. Великий бізнес України поступово переводить співробітників IT відділів, бухгалтерії, відділів маркетингу, проектування на віддалену роботу. Це зумовлено не лише бажанням роботодавця скоротити витрати на 
організацію праці, а й прагненням створити більш привабливі умови праці, утримати цінних співробітників і підвищити їхню мотивацію до праці [5, с. 543].

Нові реалії, 3 якими стикнулось людство у 2020 році, пов'язані із стрімким поширенням нового коронавірусу (COVID-19), закликають як роботодавців, так і працівників шукати компроміси та підлаштовуватись до умов віддаленої роботи. Введення режиму самоізоляції, карантину на такий тривалий термін в нашій країні, на наш погляд, актуалізує переведення майже всіх видів праці на дистанційний формат роботи (крім тих, які неможливо здійснювати у такому вигляді). Тому на цей момент науковцям усього світу важливо проаналізувати цю ситуацію та можливі проблеми, перешкоди і знайти оптимальні рішення та рекомендації, які допомогли б максимально якісно та комфортно продовжувати трудову діяльність, використовуючи особистісні та соціальні ресурси.

Аналіз останніх досліджень і публікацій. Проблеми формування та організації віддаленої роботи досліджувались такими науковцями, як А.І. Безрукова, А.А. Голев, Г.С. Гордієнко, В.В. Корольов, І.В. Кохова, А.Л. Кравченко, А.А. Нащеева, В.Б. Орлов [7, с. 10]. Практичними аспектами запровадження дистанційної форми роботи займалися Н.Ю. Сайбель, А.Н. Сорокіна, Д.О. Стребков, Є.А. Стукалкіна, Є.В. Тебеньков, Л.І. Хеддон, А. Г. Шевченко [12, с. 20]. Літературний аналіз показує, що у вітчизняній та зарубіжній теорії та практиці сформувалось декілька різних підходів до тлумачення нетипових форм зайнятості [4], які постійно вдосконалюються завдяки швидкому розвитку новітніх технологій. Актуальність нашого дослідження зумовлена обставинами сучасного світу, який потребує переходу працівників та більшості видів діяльності у формат «роботи з дому» задля збереження здоров'я та життя людей.

Постановка завдання. Метою нашої статті $€$ дослідження особливостей дистанційної роботи в умовах карантину та самоізоляції в період пандемії covid-19.

Виклад основного матеріалу дослідження. Мета нашого дослідження полягала у вивченні ставлення до цього формату праці студентів Хмельницького національного університету; виявленні зв'язків між типом темпераменту і схильністю до віддаленої роботи. Основними методами дослідження виступили аналіз наукової літератури, а також анкетне опитування респондентів на тему: «Ставлення молоді до дистанційної роботи», визначення типу вищої нервової діяльності за методикою Г. Айзенка та встановлення кореляцій між визначеним типами і ставленням до віддаленої роботи.
Варто зазначити, що дистанційна робота (телеробота, віддалена робота, робота з дому) - форма зайнятості, за якої роботодавець і найманий працівник знаходяться на значній відстані один від одного, передаючи і отримуючи технічні завдання, результати праці і оплату за допомогою сучасних засобів зв'язку, наприклад, пошти, факсу, Інтернету. Може бути постійним режимом роботи (формою зайнятості) або комбінуватися з іншими режимами праці (наприклад, коли працівник деякі дні працює - частину завдань виконує в офісі, а деякі дні - частину завдань - вдома).

Відмінними рисами дистанційної зайнятості є:

- просторова віддаленість робочого місця співробітника від місця розташування організації роботодавця;

- застосування інформаційно-комунікаційних технологій для здійснення трудової діяльності (мережа Інтернет);

- гнучкі режими організації робочого часу, графіка роботи, гнучке розташування робочого місця [7, с. 400].

Необхідно відзначити, що дистанційна зайнятість не $€$ аналогом надомної роботи, оскільки під час ії̈ реалізації спостерігаються ознаки як традиційних форм роботи за наймом, так і самозайнятості. У першому разі робота виконується в рамках індивідуального підприємництва. У другому - в рамках дії трудового договору між телепрацівниками і організацією, що не відрізняється за змістом від договорів з іншими співробітниками, при цьому робочі контакти здійснюються в реальному режимі часу, а оплата праці, навчання, кар'єрне зростання таких працівників відбуваються згідно з регламентами, які застосовуються організацією в сфері управління персоналом [1, с. 415].

Виділяють кілька різновидів дистанційної роботи:

1. Надомна телеробота (home-based telework) - вид зайнятості, за якого працівники декілька робочих днів на тиждень здійснюють трудові обов'язки вдома, використовуючи персональний комп'ютер, телефон, електронну пошту.

2. Додаткова телеробота (supplementary or occasional telework) - вид зайнятості, за якого працівники один робочий день на тиждень здійснюють трудові обов'язки вдома, використовуючи персональний комп'ютер, телефон, електронну пошту. Зазвичай цей вид зайнятості $€$ додатковим до традиційної зайнятості працівника в офісі, на офіційному робочому місці.

3. Телеробота в спеціалізованому телецентрі (centre-based telework). Це досить нова практика, коли певна організація пропонує робочі місця для співробітників сторонніх 
організацій, беручи на себе питання оснащення цих робочих місць оргтехнікою, засобами комунікації.

4. Мобільна телеробота (mobile telework) видзайнятості, заякогопрацівникиздійснюють свої трудові обов'язки щонайменше 10 годин на тиждень поза домом і поза робочим місцем в офісі (у відрядженнях, на об'єктах клієнтів, замовників, на шляху до роботи) і використовують комп'ютер для зв'язку з організацією в реальному режимі часу [5, с. 543].

Дистанційна зайнятість дає ряд переваг, як для працівника, так і для роботодавця. Для роботодавця це: економія витрат на організацію робочого місця; можливість знайти професіонала в іншому місті або країні; засіб додаткової мотивації для співробітників; скорочення витрат за рахунок зниження плати за оренду приміщення, електроенергію; високий професіоналізм віддалених співробітників і можливість отримати необхідний результат без безпосереднього контролю керівника; якісне виконання роботи.

Для працівника дистанційна зайнятість має такі переваги: можливість на свій розсуд розподіляти робочий час і працювати в комфортних для працівника умовах; можливість брати участь на ринку праці людям з обмеженими можливостями, жінкам з маленькими дітьми, студентам і пенсіонерам; можливість залучати третіх осіб до виконання тих чи інших обов'язків; дистанційна зайнятість сприяє зміцненню здоров'я, завдяки тому, що дозволяє працівнику організувати свій робочий час з урахуванням власного біологічного ритму; зниження напруження в суспільстві, пов'язане зі слабкою мобільністю населення; усунення залежності працівника від бюрократії в організаціях і жорсткості керівників; комфортний простір і відсутність дрес-коду [3, с. 18].

Проте варто враховувати і недоліки дистанційної роботи, особливо на сучасному етапі, коли людство зобов'язане тривалий час перебувати в умовах карантину та самоізоляції. До них відносять:

1) відсутність стабільності і гарантій на початковому етапі роботи;

2) необхідність великої самодисципліни, відповідальності та працездатності;
3) нерівномірний розподіл навантаження;

4) відсутність перспектив кар'єрного зростання;

5) гіподинамія, відсутність соціально зумовленої мотивації «гарно виглядати»;

6) відсутність спілкування з колегами, як формального, так і неформального.

3 метою успішного впровадження телероботи роботодавець повинен враховувати, що дистанційний співробітник може стикнутися з такими труднощами: знаходження рівноваги між роботою та особистим життям; подолання ізоляції від колег на віддаленому робочому місці; компенсація ізоляції особистого спілкування, неможливості формування особистих стосунків і взаємної довіри; компенсація недостатньої помітності; обмеження в можливості кар'єрного просування; труднощі в реалізації особистих і командних досягнень [8, с. 4]. А тому, приймаючи рішення про перехід до дистанційної роботи, співробітникові необхідно проаналізувати переваги і недоліки дистанційної зайнятості, зіставити зі своїм характером і темпераментом.

Респондентами нашого дослідження стало 123 студента, які навчаються та працюють (основначи додаткова зайнятість). У результаті проведеного в травні 2020 року анкетування студентів 4-5 курсів гуманітарно-педагогічного факультету Хмельницького національного університету було встановлено, що 39 з них (31,7\%) виявилися сангвініками, 24 (19,5\%) флегматиками, 44 юнаки та дівчата $(35,8 \%)-$ холериками і 16 (13\%) меланхоліками. Анкетування допомогло виявити кореляційні зв'язки між типом темпераменту і схильністю до певної форми організації трудової діяльності. У процесі анкетування 3'ясовано ставлення представників різних типів темпераменту до системи віддаленої праці (див. табл. 1).

Як показали результати обробки анкетування, у всіх типів темпераменту переважає позитивне ставлення до віддаленої роботи, найбільшою популярністю користувалася відповідь «переважно позитивне ставлення». Цю відповідь вибрали більше половини флегматиків і меланхоліків, дві третини сангвініків і понад дві третини холериків. У той же час абсолютно виражене позитивне ставлення

Таблиця 1

Ставлення студентів до дистанційної роботи, \%

\begin{tabular}{|c|c|c|c|c|}
\hline \multirow{2}{*}{$\begin{array}{c}\text { Ставлення до } \\
\text { дистанційної роботи } \\
\text { в умовах карантину }\end{array}$} & \multicolumn{4}{|c|}{ Тип темпераменту } \\
\hline & Сангвінік & Флегматик & Холерик & Меланхолік \\
\hline Абсолютно позитивне & 5,1 & 8,3 & 13,7 & 43,7 \\
\hline Переважно позитивне & 66,7 & 54,2 & 72,8 & 56,3 \\
\hline Байдуже & 23,1 & 21,0 & 4,5 & 0 \\
\hline Недовірливе & 0 & 16,5 & 4,5 & 0 \\
\hline Негативне & 5,1 & 0 & 4,5 & 0 \\
\hline
\end{tabular}


висловили 43,7\% меланхоліків. Примітно, що інші варіанти відповідей меланхоліки не використали, тобто всі представники цього типу темпераменту ставляться до системи віддаленої роботи, навіть в умовах самоізоляції, позитивно, що свідчить про яскраво виражену схильність меланхоліків до подібної форми організації праці. 13,7\% холериків абсолютно позитивно ставляться до віддаленої роботи та $72,8 \%$ холериків демонструють переважно позитивне ставлення до такого виду праці. Слід зазначити, що більше п'ятої частини опитуваних сангвініків і флегматиків $(23,1 \% 21,0 \%$ відповідно) ставляться до віддаленої роботи досить індиферентно. Це свідчить про їх байдуже ставлення до такої форми праці. Водночас 9\% холериків ставляться до віддаленої праці досить негативно.

Наступним етапом нашого дослідження було з'ясування причин негативного ставлення до віддаленої роботи в умовах карантину. Відповіді ми отримали, задавши респондентам питання: «Які недоліки віддаленої роботи на сучасному етапі (в період пандемії COVID-19)?». Аналіз відповідей показав, що головним недоліком половина меланхоліків і третина всіх сангвініків, холериків і флегматиків вважають неможливість отримати завдання і відправити вчасно виконану роботу в разі несправності електронних засобів комунікації. Другою за значимістю після технічної причини називають причину соціально-психо- логічну: зменшення кількості та якості контактів з людьми. На цю причину вказали більше третини представників кожного 3 чотирьох типів темпераменту (див. табл. 2).

3'ясовуючи недоліки дистанційної роботи, респондентам був запропонований вільний вибір, тобто частину відповідей студент мав можливість сформулювати сам та визначити істотно нові недоліки, які, на його думку, несприятливо впливають на працівника, а також знижують ефективність віддаленої роботи. Відкрита форма запитань сприяла виявленню таких недоліків, як: малорухливий спосіб життя (гіподинамія); відсутність зовнішнього контролю; дезорганізуюча дія домашньої обстановки; звуження спектру особистісного розвитку; ризик отримання надмірної ваги.

Також нас цікавила залежність орієнтації на віддалену роботу в майбутньому від типу темпераменту, що і зумовило питання: «Чи плануєте ви в майбутньому працювати за системою віддаленого робочого місця?» Відповіді на це питання наведені в табл. 3.

Згідно з даними, представленими в табл. 3, можна зробити висновок, що найкращим потенційним дистанційним працівником $€$ меланхолік, оскільки $56,3 \%$ респондентів з числа меланхоліків висловили готовність надалі працювати за системою віддаленої праці. Ми прогнозували, що саме меланхоліки найбільше схильні до віддаленої роботи.

Недоліки віддаленої роботи в умовах карантину, \%

Таблиця 2

\begin{tabular}{|l|c|c|c|c|}
\hline \multirow{2}{*}{ Недоліки віддаленої роботи } & \multicolumn{4}{|c|}{ Тип темпераменту } \\
\cline { 2 - 5 } & Сангвінік & Флегматик & Холерик & Меланхолік \\
\hline Зменшення кількості спілкування & 36 & 37,5 & 34,1 & 37,5 \\
\hline $\begin{array}{l}\text { Зменшення кількості знайомств з новими } \\
\text { людьми }\end{array}$ & 20,4 & 12,5 & 22,8 & 12,5 \\
\hline $\begin{array}{l}\text { Несправності технічних засобів зв'язку } \\
\text { унеможливлюють роботу }\end{array}$ & 33,4 & 33,4 & 34,1 & 50 \\
\hline Малорухливий спосіб життя (гіподинамія) & 5,1 & 0 & 0 & 0 \\
\hline Відсутність зовнішнього контролю & 0 & 8,3 & 0 & 0 \\
\hline $\begin{array}{l}\text { Низька заробітна плата та відсутність } \\
\text { кар'єрного зростання }\end{array}$ & 0 & 0 & 4,5 & 0 \\
\hline Звуження спектру особистісного розвитку & 0 & 8,3 & 0 & 0 \\
\hline Ризик отримати надлишкову вагу & 0 & 0 & 4,5 & 0 \\
\hline $\begin{array}{l}\text { Дезорганізуючий вплив «домашньої } \\
\text { атмосфери» }\end{array}$ & 5,1 & 0 & 0 & 0 \\
\hline
\end{tabular}

Таблиця 3

Залежність орієнтації на дистанційну роботу в майбутньому від типу темпераменту, \%

\begin{tabular}{|l|c|c|c|c|}
\hline \multirow{2}{*}{$\begin{array}{c}\text { Готовність у майбутньому } \\
\text { працювати на дистанційній роботі }\end{array}$} & \multicolumn{4}{|c|}{ Тип темпераменту } \\
\cline { 2 - 5 } Так & Сангвінік & Флегматик & Холерик & Меланхолік \\
\hline Hi & 10,2 & 8,3 & 22,7 & 56,3 \\
\hline Важко відповісти & 77 & 50 & 52,3 & 6,2 \\
\hline
\end{tabular}


Проте варто звернути увагу на тих, хто не зміг відповісти на це питання. Особливо великий цей показник у флегматиків. Можна припустити, що при відомій кадровій роботі (кадровий менеджмент і кадровий маркетинг) можна збільшити кількість «домашніх працівників» за рахунок представників цього психічного типу. 22,7 \% холериків та 10,2\% сангвініків також згідні в майбутньому працювати дистанційно.

Висновки 3 проведеного дослідження. Таким чином, існують значні індивідуальні особливості в здатності людей справлятися з соціальною ізоляцією та обмеженнями в період карантину під час трудової дистанційної діяльності. Важливість та актуальність максимального переведення працівників у формат віддаленої роботи зумовлюється транспортними проблемами в містах-мегаполісах, величезними і малоефективними втратами пального під час проїзду до місця роботи і назад, довготривалим перебуванням в автодорожніх «заторах», і найважливіше - безпекою життя та здоров'я в сучасних реаліях боротьби з пандемією COVID-19. Також потрібно уже в студентські роки орієнтувати майбутніх фахівців на віддалену роботу. Оскільки дистанційна робота відкриває нові можливості працевлаштування не лише для інвалідів, матусь у декретних відпустках з маленькими дітьми, але і працівників тих численних професій, чия присутність в офісі, в стінах підприємства зовсім необов'язкова. Адже їхня присутність може бути віртуальною, опосередкованою сучасними телекомунікаційними засобами зв'язку, які максимально наближають спілкування та трудові стосунки до «живого ефекту присутності».

\section{ЛІТЕРАТУРА:}

1. Голев А.А. Преимущества удаленной работы, как эфффективной занятости персонала в современных реалиях. Аллея науки. 2018. Т. 5. № 6. С. 228-231.

2. Гордиенко Г.С. Способы повышения эффрективности удаленной работы сотрудников. International Scientific Review of the Problems and Prospects of Modern Science and Education: Collection of scientific articles XLVII International correspondence scientific and practical conference. 2018. P. 72-73.
3. Королёв В.В. Учимся работать удаленно. Инновационная экономика и менеджмент: Методы и технологии: сборник материалов II Международной научно-практической конореренции. 2018. C. 47-49.

4. Кохова И.В., Петроченко Н.П. Использование нестандартных форм занятости для повышения конкурентоспособности фрирм в условиях кризиса. Актуальные проблемы социальной и экономической психологии: методология, теория, практика. Москва, 2015. С. 67-70.

5. Кравченко А.Л., Нехода Е.В. Удаленная работа и гибкий график как дополнительные мотивирующие фракторы. Управление человеческими ресурсами - основа развития инновационной экономики. 2014. № 5. С. 163-166.

6. Орлов В.Б., Бураншина Е.И. Удаленная работа как новая реалия трудовых отношений. Вестник Югорского государственного университета. 2014. № S4. C. 40-46.

7. Сорокина А.Н. Удаленная работа как нестандартная форма занятости населения региона (по материалам социологического исследования в Самарской области). Вестник Самарского государственного экономического университета. 2010. № 12. С. 63-67.

8. Стребков Д.О., Шевчук А.В., Спирина М.О. Самостоятельная работа на рынке удаленной работы. Мониторинг общественного мнения: экономические и социальные перемены. 2016. № 6. C. 88-105.

9. Тебеньков Е.В., Норкина А.Н. Удаленная работа как возможность оптимизировать расходы для бизнеса в кризис. Sciences of Europe. 2016. № 10-1. С. 55-56.

10. Хэддон Л.И., Силверстоун Р. Удаленная работа и изменение отношения «дом-работа». Инорормационное общество. 2019. № 6. С. 6-16.

11. Шевченко А. Удаленная работа: как внедрить без потерь. 2017. URL: https://prohr.rabota.ua/ udalennaya-rabotakak-upravlyat-sotrudnikami-naasstoyanii.

12. Chenneville T., Schwartz-Mette R. Ethical considerations for psychologists in the time of COVID-19. American Psychologist. 2020. P. 23-29.

13. Garfin D.R., Silver R.C., Holman E.A. The novel coronavirus (COVID-2019) outbreak: Amplification of public health consequences by media exposure. Health Psychology. 2020. 39(5). P. 355-357. 